\title{
Service Quality and Customer Retention: A Study of Microfinance Customers in Kaduna North Local Government Area, Nigeria
}

\author{
Aliyu Mamman Ph.D* Ismail Kayode Olaoye Ph.D Abdulrazaq M. AbdulRahaman Ph.D \\ Department of Business Management, Faculty of Management Sciences, Federal \\ University, Dutsin-Ma, Katsina State, Nigeria
}

\begin{abstract}
The study examined the effect of aspects of service quality (Tangibility, Reliability, Responsiveness, Assurance and Empathy) on customer retention among customers of Microfinance Banks (MFBs) in Kaduna North Local Government Area. Data was collected by means of a questionnaire administered on the 378 sampled respondents in the study area with a total population of 25,000 customers. Area random sampling technique was used in the selection of sample subjects across the local government area. Descriptive statistics in the form of frequency and percentage was used to analyze the demographic data about the respondents. Inferential statistics in the form of multiple regressions was used to determine the effect of service quality on customer retention in MFBs. The findings of the study reveal that among the aspects of service quality, empathy has the highest effect on customer retention in MFBs. Based on the finding, it is recommended that the various Managements of the MFBs in the study area should pay much attention on aspects of empathy comprising individualized attention, show of care, show of respect, show of love and friendliness to customers by staff of the MFBs.
\end{abstract}

Keywords: Service Quality, Customer retention and Microfinance banks.

DOI: $10.7176 / \mathrm{EJBM} / 12-14-04$

Publication date:May $31^{\text {st }} 2020$

\subsection{Introduction}

Globally, micro and small scale enterprises (MSSEs) play significant role in economic development. For instance in Japan, $80 \%$ of industrial labor force is employed by small firms, $50 \%$ in Germany and $46 \%$ in USA are employed by smaller businesses (https://www.ukessays.com). In Nigeria, MSSEs are positioned to absorb up to $80 \%$ of jobs, improve per capita income, increase value addition to raw materials supply and improve export earnings (Adeneji, 2015).

In spite of the critical role MSSEs play in economic development of countries, the sector is bedeviled with serious challenges in Nigeria. One of such challenges is inadequate funding and lack of access to loans from deposit money banks mainly due to absence of collateral security (Onwumere, 2017). As part of its measures to address this challenge, the Federal Government through the Central Bank of Nigeria (CBN) introduced Microfinance policy in 2005. Microfinance is the provision of financial services such as loans, savings, insurance, money transfers, and payment facilities to low income groups (Taiwo, 2012). The Microfinance policy provided the legal and regulatory framework for microfinance banking in Nigeria and is aimed at creating sustainable and credible microfinance banks (MFBs) that are capable of mobilizing and channeling funds to the MSSEs (Osalor, 2016).

From 2005 to date, a number of MFBs have been established in various parts of Nigeria; some of them licensed by CBN and some unlicensed. As at September 30, 2018, there are total of 882 licensed MFBs in Nigeria out of which Kaduna state has a total of 23. The proliferation of MFBs over the years has brought about serious competition in the sector. The competitive environment made it necessary for MFBs to initiate and adopt marketing strategies that will attract and retain customers. The importance of customer retention in a competitive environment cannot be over emphasized. LI, Yuan and Jiang (2014) maintained that increasing customer retention rates by 5\% increases profits by $25 \%$ to $95 \%$ and the likelihood of converting an existing into a repeat customer is $60 \%-70 \%$ across a range of industries. Customer retention leads to building of long term relationships that benefits both the customers and the organization through increase in the quality and quantity of exchanges. Customer retention makes the customers to build trust in the organization and also put it in a better position to understand and meet their needs.

One of the major means or strategy for customer retention in service industry like that of banks is provision of quality service (Grazhdani and Merrolari, 2015). Fatima and Gnanadhas (2011) maintained that higher quality service results in customers' satisfaction, greater willingness to recommend to someone else, reduction in complaints and improved customer retention rates. The works of Avkiran (1994), and Reichheld and Sasser (1990) also confirmed the importance of quality service in expansion of market share and maximization of return on investment.

Over the years, measurement of quality service was mostly restricted to physical products. In view of the 
increasing importance of the service sector in the economy, Researchers have developed models or tools that can be used in measuring service quality in respect of intangible products like that of banking services. This study will adopt the SERVQUAL model, developed by Parasuraman and Zethaml (1985:1988) in measuring service quality of Microfinance banks in Kaduna North local government area, as perceived by customers. The model is based on five service quality areas, namely, tangibility, reliability, responsiveness, assurance and empathy. The model have been adopted by many scholars in the study of quality service in respect of commercial or money deposit banks in Nigeria but there are few studies in respect of Microfinance banks as they are relatively young and are still passing through developmental challenges (Ibok and Udofor, 2012). This is the gap this paper intends to fill.

The general objective of the paper is to determine the effect of service quality on retention of customers by MFBs operating in Kaduna North Local government Area. The specific objectives of the study are (i) to determine the effect of tangibility on customer retention by MFBs (ii) to determine the effect of reliability on customer retention by MFBs (iii) to determine the effect of responsiveness on customer retention by MFBs (iv) to determine the effect of assurance on customer retention by MFBs and (v) to determine the effect of empathy on customer retention by MFBs.

\subsection{Literature Review 2.1 Conceptual Review \\ 2.1.1 Service Quality}

Service quality is defined as the customer's overall impression of the relative inferiority or superiority of the service being provided ( Bashir, Machali and Mwinyi, 2012). Lewis and Booms (1983) define Quality Service as a measure of how well the services rendered meets the expectations of customers. The areas of expectations constitute dimensions of quality service. Arlen (2018) described the five SERVQUAL dimensions of quality service as follows: tangibles; this entails appearance of physical facilities, equipment, personnel and communication materials; reliability; this entails the ability of the service provider to provide service dependably and accurately which involvesprompt service delivery, provision of wide range of value added products, security of transactions and customer information; responsiveness; this involves willingness to help customers and provide prompt service which is manifested in staff willingness to assist customers promptly, answering customers enquiries on time, provision of correct service at the first time and provision of fast and efficient service at the counter: assurance; this refers to knowledge and courtesy of staff and their ability to convey trust and confidence to customers: and finally empathy; this entails the caring and individualized attention the staff provide to customers If the services being rendered are able to meet up with the customers' expectations in the five dimensions then the customers are satisfied and can be retained by the service provider, in our own case the MFBs.

\subsubsection{Customer Retention}

Customer retention comprises measures taken by business organizations to ensure persistent patronage of a product or service by customers over a long period of time (Gbolagade and Abubakar, 2018). Customer retention is also defined as the activities and actions business organizations take to reduce the number of customer defections (https://www.ngdata.com). According to Roking (2005), Customer retention involves measures adopted by organizations to minimize customer defections, which normally start from initial contact with a customer and continue throughout the entire lifetime of a relationship. The goal of customer retention policy is to help business organizations retain as many customers as possible, over a long period of time, mainly through customer loyalty and brand loyalty programmes ((https://www.ngdata.com).

The relationship between the five service dimensions, customer satisfaction and retention can be depicted as follows:

Figure 1

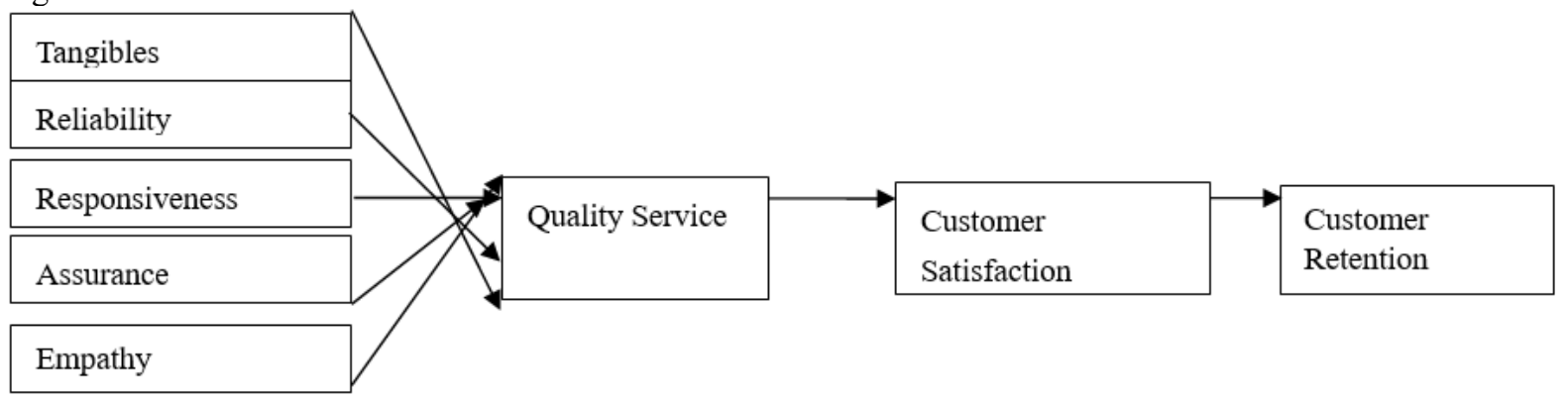

Source: Authors depiction, 2019

2.1.3 Microfinance Banks

Microfinance Banks (MFBs) are financial institutions licensed by the CBN to provide credit, savings and other essential financial services that are needed by the economically active poor, micro, small and medium enterprises 
that cannot be efficiently served by regular commercial banks because their activities and volumes are too low to warrant the high cost of services by these big banks (Ibok and Udofor, 2012). According to Obokoh, Jegede, Akinlabi and Olajide (2012), the development objectives of the MFBs generally include to reduce poverty, empower women and more rural entrepreneurs, create employment, help existing business grow or diversify their activities, encourage the development of a new business. Abiola, (2012) agree that microfinance is about providing financial services to the poor who are traditionally not served by the conventional financial institutions. Microfinance is mostly used in developing economies where micro enterprises do not have access to other sources of financial assistance (Bashir et al, 2012). MFBs recognize poor and micro entrepreneurs who are excluded or denied access to financial services on account of their inability to provide tangible assets as collateral for credit facilities (Taiwo, 2012). As at $30^{\text {th }}$ September, 2018 the CBN has licensed a total of 882 MFBs out of which eight (8) are located in Kaduna North Local government area.

\subsection{Review of Empirical Literature}

Bashir, et al (2012) conducted a study on the effect of service quality on customer satisfaction in respect of MFBs customers in Kenya. The study revealed a positive relationship between service quality and customer satisfaction and by implication customer retention

Ojo (2010) investigated the relationship between service quality and customer satisfaction in the Nigerian telecommunication industry and he also found positive relationship between service quality and customer satisfaction and retention.

Ihaamie (2010) employed the SERQUAL model developed by Parasuraman et al, 1988 with five dimensions to examine the level of service quality, expectation and perception of customers about the Malaysian public services. The study discovered that among the five dimensions, customers perceived tangibility as the most important in service quality, customer satisfaction and customer retention.

Using the SERQUAL instrument, Kheng, Muhammad, Ramayah and Mosahab (2010) evaluated the impact of service quality on customer loyalty among bank customers in Penang, Malaysia. The findings of the study revealed that the service quality dimensions of reliability, empathy and assurance (in order of priority) play a significant role in customers' perception of service quality, loyalty and retention.

Harr (1982) conducted an exploratory study of customer satisfaction of fine dining restaurants in in Singapore. The study discovered that the service dimensions of assurance, empathy and tangibles (in order of priority) are the most critical to customers' evaluation of service quality and by implication customers' satisfaction and retention.

Ibok and Udofor (2012) analyzed the drivers and inhibitors with regard to customer retention by MFBs in Akwa Ibom State, Nigeria. The study found that among the five service dimensions, tangibility has the highest positive effect on customers'perception of quality service, customer satisfaction and retention.

Kanyurhi (2013) evaluated customer satisfaction with the services of MFBs in Togo and the finding of the study revealed that the service dimension of responsiveness remain the most important determinant of customer satisfaction and retention.

\subsection{Methodology}

\subsection{Research Design}

The general objective of the study is to determine the effect of service quality on retention of customers by MFBs operating in Kaduna North Local government Area. To achieve this objective the survey research design was adopted. The survey was conducted by means of administration of questionnaires on respondents and collection of data using the cross-sectional method in which data was collected once during period of the study.

\subsection{Population of the Study}

The target population of this study includes customers of selected MFBs operating in the Kaduna North Local Government Area. The three selected banks have a total customer population of 25,000 (Kaduna North Association of MFBs, 2018).

\subsection{Sample Size and Sampling Technique}

Based on the formula given by Krejcie and Morgan, (1970) a sample of 378 was arrived at as follows:

$\mathrm{s}=\mathrm{X}^{2} \mathrm{NP}(1-\mathrm{P}) \div \mathrm{d}^{2}(\mathrm{~N}-1)+\mathrm{X}^{2} \mathrm{P}(1-\mathrm{P})$

$\mathrm{S}=$ required sample size.

$\mathrm{X}^{2}=$ the table value of chi-square for 1 degree of freedom at the desired confidence level (3.841).

$\mathrm{N}=$ the population size.

$\mathrm{P}=$ the population proportion (assumed to be .50 since this would provide the maximum sample size).

$\mathrm{d}=$ the degree of accuracy expressed as a proportion $(.05)$.

$\mathrm{S}+=\quad 3.841(25,000)(0.50)(0.50)$

$0.05^{2}(25,000)+3.841(0.50)(0.50)$ 


$$
\begin{aligned}
& \mathrm{S}=\quad \frac{24,006.25}{62.5+0.96025} \\
& \mathrm{~S}=\quad 378.29 \approx 378
\end{aligned}
$$

The quota for the sample size in each bank was arrived at using this formula:

Sample Size x No of Customers in each Bank

Total Population

Eg for Abokie Microfinance Bank $=\frac{378}{25000} \times 2000=30$

The random sampling technique was used in administering the questionnaires among the sample subjects within the banks under study.

\subsection{Method of Data Collection}

The instrument for measuring quality in service referred to as SERVQUAL, developed by Parasuraman and Zethaml (1985:1988) was used in generating primary data for the study. The items in the instrument reflect five service quality areas, namely, tangibility, reliability, responsiveness, assurance and empathy measured on the five point Likert scale of "Strongly Agree" "Agree" "Undecided" "Disagree" Strongly Disagree". The level of customer retention due to quality service was also measured using the same five point Likert scale from "Strongly Agree" to "Strongly Disagree"

\subsection{Method of Data Analysis}

The study employed descriptive and inferential statistics in analyzing the data collected. The descriptive statistics was used in analyzing the demographic data of respondents. Inferential statistics in the form of multiple regression technique was used to determine the effect of quality service on customer retention. The dependent variable (customer retention) was regressed on the independent variable (service quality that comprises the five services dimensions of tangibility, reliability, responsiveness, assurance and empathy) using regression model as follows $\mathbf{C R}=\boldsymbol{\alpha}_{\mathbf{o}}+\boldsymbol{\alpha}_{\mathrm{tos}} \mathbf{X}_{\mathrm{tos}}+\boldsymbol{\alpha}_{\mathrm{rel}} \mathbf{X}_{\mathrm{rel}}+\boldsymbol{\alpha}_{\mathrm{res}} \mathbf{X}_{\mathrm{res}}+\boldsymbol{\alpha}_{\mathrm{ass}} \mathbf{X}_{\mathrm{ass}}+\boldsymbol{\alpha}_{\mathrm{emp}} \mathbf{X}_{\mathrm{emp}}+\partial \ldots$

\subsection{Factors Management}

For easy data analysis, factor analysis was used for data reduction as well as structure detection. This is to forestall the challenge of data management and utilization, through the removal of redundant (highly correlated) variables. In all cases and on the basis of Kaiser's criterion (1958) of Eigen value $>1$, factors with Eigen value of 1.0 and above were selected.

Table 3.1: Total Variance Explained - Customer Retention (CR)

\begin{tabular}{|c|c|c|c|c|c|c|}
\hline \multirow{2}{*}{ Component } & \multicolumn{3}{|c|}{ Initial Eigen values } & \multicolumn{3}{c|}{ Extraction Sums of Squared Loadings } \\
\cline { 2 - 7 } & Total & \% of Variance & Cumulative \% & Total & \% of Variance & Cumulative \% \\
\hline 1 & 2.998 & 59.966 & 59.966 & 2.998 & 59.966 & 59.966 \\
2 & .676 & 13.521 & 73.487 & & & \\
3 & .565 & 11.292 & 84.779 & & & \\
4 & .437 & 8.734 & 93.513 & & & \\
5 & .324 & 6.487 & 100.000 & & & \\
\hline
\end{tabular}

Extraction Method: Principal Component Analysis.

Table 3.2: CR Component Matrix ${ }^{a}$

\begin{tabular}{|l|c|}
\hline & Component \\
\cline { 2 - 2 } & 1 \\
\hline CR1 & .745 \\
CR2 & .783 \\
CR3 & .767 \\
CR4 & .733 \\
CR5 & .839 \\
\hline
\end{tabular}

Extraction Method: Principal Component Analysis. 
Table 3.1: Total Variance Explained - Customer Retention (CR)

\begin{tabular}{|c|c|c|c|c|c|c|}
\hline \multirow{2}{*}{ Component } & \multicolumn{3}{|c|}{ Initial Eigen values } & \multicolumn{3}{c|}{ Extraction Sums of Squared Loadings } \\
\cline { 2 - 7 } & Total & \% of Variance & Cumulative \% & Total & \% of Variance & Cumulative \% \\
\hline 1 & 2.998 & 59.966 & 59.966 & 2.998 & 59.966 & 59.966 \\
2 & .676 & 13.521 & 73.487 & & & \\
3 & .565 & 11.292 & 84.779 & & & \\
4 & .437 & 8.734 & 93.513 & & & \\
5 & .324 & 6.487 & 100.000 & & & \\
\hline
\end{tabular}

Table 3.3: Total Variance Explained - Tangibility of Service (TOS)

\begin{tabular}{|l|r|r|r|r|r|r|}
\hline \multirow{2}{*}{ Component } & \multicolumn{3}{|c|}{ Initial Eigen values } & \multicolumn{2}{|c|}{ Extraction Sums of Squared Loadings } \\
\cline { 2 - 7 } & Total & \% of Variance & Cumulative \% & Total & \% of Variance & Cumulative \% \\
\hline 1 & 2.973 & 59.458 & 59.458 & 2.973 & 59.458 & \\
3 & .684 & 13.679 & 73.137 & & & \\
4 & .569 & 11.371 & 84.508 & & & \\
5 & .423 & 8.458 & 92.966 & & & \\
\hline
\end{tabular}

Extraction Method: Principal Component Analysis.

Table 3.4: TOS Component Matrix ${ }^{a}$

\begin{tabular}{|c|c|}
\hline & Component \\
\cline { 2 - 2 } & 1 \\
\hline TOS1 & .743 \\
TOS2 &. $\mathbf{8 5 2}$ \\
TOS3 & .687 \\
TOS4 & .791 \\
TOS5 & .773 \\
\hline
\end{tabular}

Extraction Method: Principal Component Analysis.

Table 3.5: Total Variance Explained - Reliability (REL)

\begin{tabular}{|l|r|r|r|r|r|r|}
\hline \multirow{2}{*}{ Component } & \multicolumn{3}{|c|}{ Initial Eigenvalues } & \multicolumn{2}{|c|}{ Extraction Sums of Squared Loadings } \\
\cline { 2 - 7 } & Total & \% of Variance & Cumulative \% & Total & \% of Variance & Cumulative \% \\
\hline 1 & 2.474 & 49.488 & 49.488 & 2.474 & 49.488 & 49.488 \\
2 & .860 & 17.192 & 66.681 & & & \\
3 & .677 & 13.534 & 80.215 & & & \\
4 & .506 & 10.124 & 90.339 & & & \\
5 & .483 & 9.661 & 100.000 & & & \\
\hline
\end{tabular}

Extraction Method: Principal Component Analysis. 
Table 3.6: REL Component Matrix ${ }^{a}$

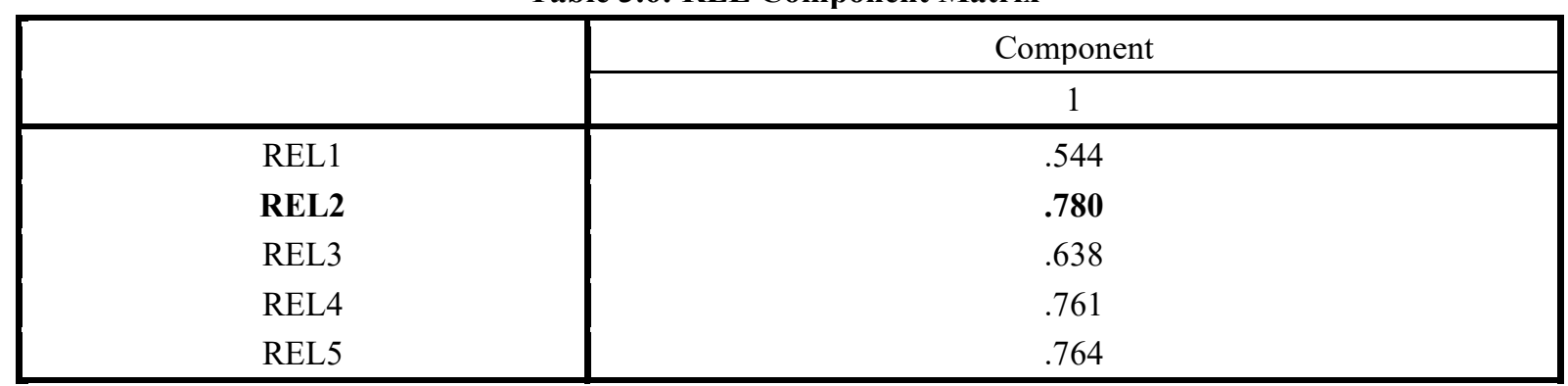

Extraction Method: Principal Component Analysis.

Table 3.7: Total Variance Explained - Responsiveness (RES)

\begin{tabular}{|l|r|r|r|r|r|r|}
\hline \multirow{2}{*}{ Component } & \multicolumn{3}{|c|}{ Initial Eigenvalues } & \multicolumn{2}{|c|}{ Extraction Sums of Squared Loadings } \\
\cline { 2 - 7 } & Total & \% of Variance & Cumulative \% & Total & \% of Variance & Cumulative \% \\
\hline 1 & 2.669 & 53.372 & 53.372 & 2.669 & 53.372 & \\
2 & .777 & 15.537 & 68.909 & & & \\
3 & .685 & 13.709 & 82.618 & & & \\
4 & .500 & 9.997 & 92.615 & & & \\
5 & .369 & 7.385 & 100.000 & & & \\
\hline
\end{tabular}

Extraction Method: Principal Component Analysis.

Table 3.8: RES Component Matrix ${ }^{a}$

\begin{tabular}{|l|c|}
\hline & Component \\
\cline { 2 - 3 } & RES1 \\
\hline RES2 & .749 \\
RES3 & .817 \\
RES4 & .630 \\
RES5 & .790 \\
\hline
\end{tabular}

Extraction Method: Principal Component Analysis.

Table 3.9: Total Variance Explained - Assurance (ASS)

\begin{tabular}{|l|r|r|r|r|r|r|}
\hline \multirow{2}{*}{ Component } & \multicolumn{3}{|c|}{ Initial Eigenvalues } & \multicolumn{3}{c|}{ Extraction Sums of Squared Loadings } \\
\cline { 2 - 7 } & Total & \% of Variance & Cumulative \% & Total & \% of Variance & Cumulative \% \\
\hline 1 & 2.980 & 59.593 & 59.593 & 2.980 & 59.593 & 59.593 \\
2 & .797 & 15.939 & 75.533 & & & \\
3 & .477 & 9.536 & 85.068 & & & \\
4 & .441 & 8.814 & 93.882 & & & \\
5 & .306 & 6.118 & 100.000 & & & \\
\hline
\end{tabular}

Extraction Method: Principal Component Analysis. 
Table 3.10: ASS Component Matrix ${ }^{a}$

\begin{tabular}{|c|c|}
\hline & Component \\
\cline { 2 - 3 } & ASS1 \\
\hline ASS2 & .732 \\
ASS3 & .717 \\
ASS4 & $\mathbf{. 8 5 4}$ \\
ASS5 & .744 \\
& .804 \\
\hline
\end{tabular}

Extraction Method: Principal Component Analysis.

Table 3.11: Total Variance Explained - Empathy (EMP)

\begin{tabular}{|l|r|r|r|r|r|r|}
\hline \multirow{2}{*}{ Component } & \multicolumn{3}{|c|}{ Initial Eigenvalues } & \multicolumn{2}{|c|}{ Extraction Sums of Squared Loadings } \\
\cline { 2 - 7 } & \multicolumn{1}{|c|}{ Total } & \% of Variance & Cumulative \% & Total & \% of Variance & Cumulative \% \\
\hline 1 & 3.171 & 63.423 & 63.423 & 3.171 & 63.423 & \\
2 & .631 & 12.624 & 76.047 & & \\
3 & .498 & 9.958 & 86.005 & & & \\
4 & .423 & 8.456 & 94.461 & & & \\
5 & .277 & 5.539 & 100.000 & & & \\
\hline
\end{tabular}

Extraction Method: Principal Component Analysis.

Table 3.12: EMP Component Matrix ${ }^{a}$

\begin{tabular}{|c|c|}
\hline & Component \\
\cline { 2 - 3 } & EMP1 \\
\hline EMP2 & .702 \\
EMP3 & .802 \\
EMP4 & .786 \\
EMP5 & .865 \\
& .819 \\
\hline
\end{tabular}

Extraction Method: Principal Component Analysis.

For customer retention (CR) only one factor with eigen value of 2.996 was selected as it represents about $59.666 \%$ of the total variance within the variable. All the other factors have less than 1.0 eigen values and so were discarded with. In table 3.2, the factor CR5 was confirmed to be the chosen factor as it has the highest component score of 0.839 .

For tangibility of service (ToS), the only component with eigen factor higher than 1.0 was picked with an eigen factor of 2.973 representing $59.458 \%$ (table 3.3) of all variance within the factors of the variable. This was confirmed to be factor ToS2 (see table 3.4) with a component score of 0.852 . The same thing applies to the other factors with components REL2 (eigen value $=2.474$; 49.488\%; component score $=0.780$ ) (tables 3.5 and 3.6); RES2 (eigen value $=2.669 ; 53.372 \%$; component score $=0.817)($ tables 3.7 and 3.8); ASS3 (eigen value $=2.980 ; 59.593 \%$; component score $=0.854$ ) (tables 3.9 and 3.10$)$ and EMP4 (eigen value $=3.171 ; 63.423 \%$; component score $=0.865$ ) (tables 3.11 and 3.12) representing Reliability (REL), Responsiveness (RES), Assurance (ASS) and Empathy (EMP) respectively.

Therefore, for the model

$\mathrm{CR}=\alpha_{\mathrm{o}}+\alpha_{\mathrm{tos}} \mathrm{X}_{\text {tos }}+\alpha_{\text {rel }} \mathrm{X}_{\text {rel }}+\alpha_{\text {res }} \mathrm{X}_{\text {res }}+\alpha_{\text {ass }} \mathrm{X}_{\mathrm{ass}}+\alpha_{\mathrm{emp}} \mathrm{X}_{\mathrm{emp}}+\partial \ldots$ therefore, the following factors were extracted:

CR5 (0.839), ToS2 (0.852), REL2 (0.780), RES2 (0.817), ASS3 (0.854) and EMP4 (0.865)

\subsection{Validity and Reliability of Research Instrument}

The instrument of this research work, being adapted from SERVQUAL as developed by Parasuraman and Zethaml (1988) and modified to reflect customer retention contains 34 items divided into 6 sections. This was tested for reliability and validity and scored 0.89 on the Cronbach's Alpha scale (see Table 3.13). It is noteworthy to point out that the instrument had about 91\% (0.911) Cronbach's Alpha score when standardized items are used. 
Table 3.13: Reliability Statistics

\begin{tabular}{|r|r|r|r|}
\hline Cronbach's Alpha & Cronbach's Alpha Based on Standardized Items & N of Items \\
\hline .893 & .911 & 34 \\
\hline
\end{tabular}

\subsection{Result and Discussion of Findings}

\subsection{Descriptive Statistics}

\section{Crosstab}

Table 4.1: Age of respondent and Patronage

\begin{tabular}{|c|c|c|c|c|c|c|}
\hline & \multicolumn{4}{|c|}{ Patronage } & \multirow{2}{*}{ Total $(\%)$} \\
\hline & & $<5$ & $5-10$ & $11-20$ & $>20$ & \\
\hline \multirow{5}{*}{ AGE } & $<30$ & 5 & 0 & 1 & 3 & $9(7 \%)$ \\
\hline & $30-35$ & 4 & 12 & 0 & 0 & $16(12.40)$ \\
\hline & $36-40$ & 3 & 4 & 4 & 2 & 13 (10.08) \\
\hline & $41-50$ & 9 & 8 & 2 & 2 & $21(16.28)$ \\
\hline & $>50$ & 13 & 39 & 13 & 5 & $70(54.26)$ \\
\hline \multicolumn{2}{|c|}{ Total (\%) } & $34(26.36)$ & $63(48.84)$ & $20(15.50)$ & $12(9.30)$ & $129(100)$ \\
\hline
\end{tabular}

The cross-tabulation of the age of the respondents and length of patronage revealed that the highest proportion of patronage comes from the above 50 age bracket especially over a period of 5 to 20 years with more than $50 \%$ of the age range. They constitute $54.26 \%$ of the entire respondents.

\section{Crosstab}

Table 4.2: Age/Account type

\begin{tabular}{|c|c|c|c|c|c|c|}
\hline & \multicolumn{4}{|c|}{ Account } & \multirow{2}{*}{ Total (\%) } \\
\hline & & Savings & Current & Deposit & Others & \\
\hline \multirow{6}{*}{ AGE } & $<30$ & 2 & 5 & 2 & 0 & $9(7.5 \%)$ \\
\hline & $30-35$ & 8 & 5 & 2 & 0 & 15 (12.50) \\
\hline & $36-40$ & 3 & 5 & 2 & 0 & $10(8.33)$ \\
\hline & $41-50$ & 6 & 10 & 4 & 0 & $20(16.67)$ \\
\hline & $>50$ & 51 & 11 & 1 & 3 & $66(55.00)$ \\
\hline & Total (\%) & $70(58.33)$ & $36(30.00)$ & 11(9.17) & $3(2.5)$ & $120(100)$ \\
\hline
\end{tabular}

The type of account operated by each respondent is categorized under four headings: Savings, Current, Deposit and others. when cross-tabulated with Age of respondents it revealed that bulk of respondents operate savings accounts; constituting about $58.33 \%$ of the entire responses. Likewise, the over 50 years age bracket constitute the bulk of the savings account operators (about $72 \%$ ). Also people within this age bracket are the ones requiring specialized banking service as about $5 \%$ of them are the only utilizers of these kinds of services.

\section{Crosstab}

Table 4.3: Gender/Patronage

\begin{tabular}{|cc|c|c|c|c|c|}
\hline & \multicolumn{5}{|c|}{ Patronage } & \multirow{2}{*}{ Total (\%) } \\
\cline { 2 - 7 } & 1 & 2 & 3 & 4 & \\
\hline \multirow{2}{*}{ Gender } & Male & 15 & 35 & 13 & 8 & $\mathbf{7 1 ( 5 6 . 8 0 )}$ \\
& Female & 18 & 28 & 6 & 2 & $\mathbf{5 4 ( 4 3 . 2 0 )}$ \\
\multicolumn{2}{|c|}{ Total (\%) } & $\mathbf{3 3}(\mathbf{2 7 . 5})$ & $\mathbf{6 3 ( 5 0 . 4 )}$ & $\mathbf{1 9}(\mathbf{1 5 . 2})$ & $\mathbf{1 0}(\mathbf{8})$ & $\mathbf{1 2 5}$ \\
\hline
\end{tabular}

Gender and patronage was cross-tabulated to see the trend of gendered interest in community banking. Table 4.3 indicated that most women are new to community banking or rather men have longer period of patronage compared to women. Most of the female respondents $(85.18 \%)$ are relatively new patrons of community banking compared to the male respondents $(71.43 \%)$. 


\section{Crosstab}

Table 4.4: Gender/Account type

\begin{tabular}{|c|c|c|c|c|c|}
\hline & \multicolumn{4}{|c|}{ Account } & \multirow{2}{*}{ Total $(\%)$} \\
\hline & Savings & Current & Deposit & Others & \\
\hline \multirow{3}{*}{$\begin{array}{cc}\text { Gender } & \text { Male } \\
& \text { Female } \\
\text { Total }\end{array}$} & 39 & 20 & 8 & 2 & $69(58.97)$ \\
\hline & 29 & 16 & 2 & 1 & $48(41.03)$ \\
\hline & $68(58.12)$ & $36(30.77)$ & $10(8.55)$ & $3(2.6)$ & 117 \\
\hline
\end{tabular}

Cross-tabulation of gender of respondents and account type operated revealed that $29(54.17 \%)$ of the female operate savings account while it is $56.52 \%$ of the male sampled.

\subsection{Regression Results}

In table 4.5 , the multiple correlation coefficient $R$ indicates that there is a slightly obvious relationship between the model-predicted and observed values of the dependent variable while the coefficient of determination, $R^{2}$, indicates that only about $22.5 \%$ of the variation in customer retention is explained by the model. This indicates that other factors are responsible for $77.5 \%$ of the variability in customer retention.

Table 4.5: Model Summary

\begin{tabular}{|l|c|r|r|r|}
\hline Model & \multicolumn{1}{|c|}{$\mathrm{R}$} & \multicolumn{1}{|c|}{ R Square } & Adjusted R Square & \multicolumn{1}{c|}{ Std. Error of the Estimate } \\
\hline 1 & $.474^{\mathrm{a}}$ & .225 & .191 & .533 \\
\hline
\end{tabular}

a. Predictors: (Constant), Tangibility of Service, Reliability, Responsiveness, Assurance, Empathy

Table 4.6 shows that the model accounted for just about a quarter of all variation although the significant value of the $F$ statistics is less than 0.05 ; indicating that the variation explained by the model is not due to chance and is therefore considered significant.

Table 4.6: $\operatorname{ANOVA}^{\mathrm{b}}$

\begin{tabular}{|ll|r|r|r|r|r|}
\hline Model & & Sum of Squares & Df & Mean Square & F & Sig. \\
\hline 1 & Regression & 9.545 & 5 & 1.909 & 6.721 & $.000^{\mathrm{a}}$ \\
& Residual & 32.947 & 116 & .284 & & \\
& Total & 42.492 & 121 & & & \\
\hline
\end{tabular}

a. Predictors: (Constant), Tangibility of Service, Reliability, Responsiveness, Assurance, Empathy

b. Dependent Variable: Customer Retention

Table 4.7: Coefficients ${ }^{\mathrm{a}}$

\begin{tabular}{|c|c|c|c|c|c|}
\hline \multirow[b]{2}{*}{ Model } & \multicolumn{2}{|c|}{ Unstandardized Coefficients } & \multirow{2}{*}{$\frac{\text { Standardized Coefficients }}{\text { Beta }}$} & \multirow[b]{2}{*}{$\mathrm{T}$} & \multirow[b]{2}{*}{ Sig. } \\
\hline & B & Std. Error & & & \\
\hline 1 (Constant) & 2.001 & .499 & & 4.011 & .000 \\
\hline Tangibility of Service & .068 & .077 & .079 & .872 & .385 \\
\hline Reliability & -.008 & .087 & -.008 & -.089 & .929 \\
\hline Responsiveness & .010 & .092 & .011 & .113 & .910 \\
\hline Assurance & .048 & .081 & .060 & .600 & .550 \\
\hline Empathy & .446 & .092 & .435 & 4.869 & .000 \\
\hline
\end{tabular}

a. Dependent Variable: Customer Retention

Tangibility of Service, Reliability, Responsiveness and Assurance seems to be less important predictors of Customer Retention by Micro Finance Banks, as they all have very low coefficients and they also contribute less to the overall model as implied by the corresponding low absolute standardized coefficients. Thus, all have no significant effect on Customer Retention. Empathy, however, has a very high effect on customer retention as indicated by the high standardized coefficient $(B=0.435)$ and a significant $p$-value $(p=0.000)$ that is less than 0.05 . This could be as result of the overriding influence of cultural empathy, where everyone is a lookout for the other; sharing feelings, emotions, bereavements and joyous moments.

\subsection{Conclusion and Recommendations}

The outcome of the statistical analysis conducted in this study has shown that Customer Retention is influenced 
by several factors that fall outside normal apriori expectations. Tangible service may be deemed to be an essential ingredient in determining whether customers will remain committed to a particular brand or not, but it appears Micro-Finance Bank customers in the Kaduna area are less inclined to stay because of it; likewise for reliability, responsiveness and assurance. However, empathy is indicated as the major and only determinant of Customer Retention in Micro-Finance Banks in Kaduna metropolis. It will be safe to adduce that all the other factors without empathy will amount to naught in the estimation of the customers. One can have tangible service that is devoid of the understanding of the feelings of the customer or an assurance of getting served without due consideration for the channel of service delivery as it impacts the emotion of the customer.

In view of the foregoing the study recommends that MFBs in the study area should pay much attention on aspects of Empathy as follows:

I. Adoption of policies and practices that make staff to render services to customers as individualized or personal products to them;

II. Show of more care by staff of MFBs in their interaction with customers;

III. Exhibition of high degree of respect by staff of MFBs in dealing with customers;

IV. Show of high degree of love by staff of MFBs to customers in handling all their issues;

V. Show of high degree of friendliness by staff of MFBs in all their interaction with all categories of customers.

\section{References}

Abiola, B. (2012). Effect of Microfinance on Micro and Small Enterprises (MSEs) Growth in Nigeria. Journal of Business and Management Sciences, 2(4), 190-195.

Adeneji, E. (2015). The Nigerian Economy: The Role of SMEs, https://connectnigeria.com. Retrieved January 28,2019

Arlen, C. (2018). The 5 Service Dimensions All Customers Care About http://www.serviceperformance.com. Retrieved January 28, 2019

Avkiran, N. (1994). Developing an Insrument to Measure Customer Service Quality in Branch. International Journal of Bank Marketing, 12 (6) , 10-18.

Bashir, S., Machali, M. M., \& Mwinyi, M. A. (2012). The Effect of Service Quality and Government Role on Customer Satisfaction: Empirical Evidence of Microfinance in Kenya. International Journal of Business and Social Science, Vol 3, No 14, 312-319.

Fatima, H., \& Gnanadhas, E. (2011). Impact of Service Quality in Commercial Banks on the Customers' Satisfaction: An Empirical Study. International Journal of Multidisciplinary Research, Vol Issue 6, 19-37.

Gbolagade, L., \& Abubakar, A. (2018). Determinants of Customer Retention in Deposit Money Banks in DutsinMa, Nigeria. Ilorin Journal of Human Resource Management, Vol 2, No 1, 127-136.

Grazhdani, S., \& Merrolari, K. (2015). The Influence of Demographic Factor on Customer Service Quality Perception. Earopean Journal of Economics and Business Studies , 155-167.

Harr, K. L. (1982). Service Dimensions of Service Quality Impacting Customer Satisfaction of Fine Dining Restraunts in Singapore. Las Vegas: Unpublished Masters Thesis, Graduate School University of Nevarda.

Ibok, N., \& Udofor, P. O. (2012). Customers' Retention in Micro Finance Banks: An Analysis of Drivers and Inhibitors. International Journal of Marketing Studies, Vol 4, No5 , 74-80.

Ihaamie, A. (2010). Service Quality in Malaysian Public Service: Some Findings. International Journal of Trade, Economics and Finance, Vol 1 No 1 , 15-30.

Importance of Small and Medium Enterprises in Nigeria. (n.d.). Retrieved January 28, 2019, from https://www.ukessays/essays/economics/importance- of-sma.

Kaduna North Local Government Area, Association of Microfiance Banks (2018).

Kaiser, H. F. (1958). The varimax criterion for analytic rotation in factor analysis.

Psychometrika, 23, 187-200.

Kanyurhi, B. E. (2013). Evaluation of Customer Satisfaction with Services of a Micro-finance Institution: Empirical Evidence from Women Association for Social and Economic Gain Customers in Togo. African Journal of Marketing Management, Vol 5(2) , 26-37.

Kheng, L., Muhammad, O., Ramayah, T., \& Mosahab, R. (201). The impact of Service Quality on Customer Loyalty: A Study of Banks in Penang, Malaysia. International Journal of Marketing Studies, Vol 2 No 2 , 57 66.

Krejcie, W., \& Morgan, D. (1970). Determining Sample Size for Research Activities in Educational and Psychological Measurements. London: Longman.

Lewis, R., \& Booms, B. H. (1983). The Marketing Aspect of Service Quality. Journal of Emerging Perspectives, Vol 8 No 1, 99-107.

Li, L., Yuan, S. M., \& Jiang, N. (2014). An Analysis of the Influencing Factors of Customer Retention in Tourism Resort Industry: A Case Study of Lingnan Impression Park, Guangzhou, China. Eurasian Journal of Business 
and Management, 2 (2) , 1-13.

Obokoh, T., Jegede, C. A., Akinlabi, B. H., \& Olajide, O. (2012). Empirical Study of the Impact of MFBs on Small and Medium Enterprises in Nigeria. Journal of Academic Research in Economics and Management Science, 2(6) , 226-231.

Ojo, O. (2010). The Relationship Between Service Quality and Customer Satisfaction in the Telecommunication Industry: Evidence from Nigeria. BRAND Broad Research in Accounting, Negotiation and Distribution, Vol, Issue 1, 88-100.

Onwumere, O. (2017). https://allafrica.com. Retrieved January28 2019

Osalor, P. (2016). https://www.vanguardngr.com. Retrieved January 2018, 2019

Parasuraman, A., Zeithaml, V. A., \& Berry, L. L. (1985). A Conceptual Model of Service Quality and its Implications. Journal of Marketing Vol 49, Fall , 41-50.

Parasuraman, A., Zeithaml, V. A., \& Berry, L. 1. (1988). SERVQUAL: A Multi-item Scale for Measuring Consumer Perception of the Service Quality. Journal of Retailing, Vol 67, 12-40.

Reichheld, F., \& Sasser, E. W. (1990, September-October). Zero Defections: Quality Comes to Service. Harvard Business Review, pp. 105-111.

Roking, L. (2005). Industrial Organization and Consumer Satisfaction/Dissatisfaction. Journal of Consumer Research, 9(2) , 12-26.

Taiwo, J. (2012). The Impact of Microfinance on Welfare and Poverty Alleviation in South-West Nigeria. Covenant University, Ota: Unpublished Ph.D Thesis. 